\title{
22. 上顎癌の治療の現況
}

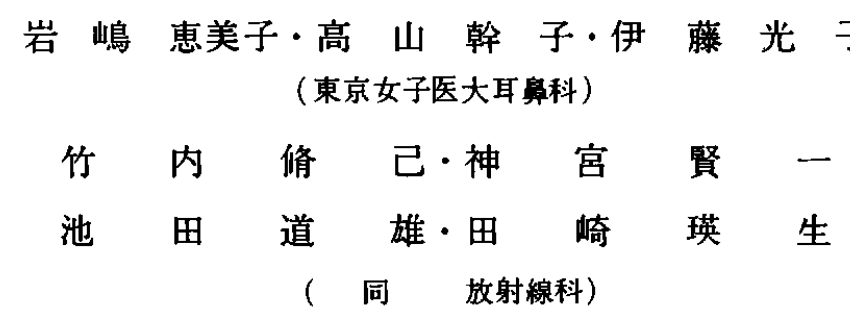

東京女子医大において昭和 41 月 10 月から 49 年 9 月ま でに上頻癌として治療を行なった 52 名のうち 3 年以上 経過観察を行なった 31 症例の治療法別生存率を検討し てみると

$\mathbf{A}(\mathbf{a})$ 動注と術前照射同時併用後手術を行ない経過良好 のため術後照射を行なかなかったもの80\%（4/5）

(b)動注と術前照射同時併用後手術を行なってから術 後照射（外部または腔内）を行なったもの $56 \%(5 / 9)$

B 術前照射をしてから手術を行なったもの $50 \%(3 / 6)$

C 手術をしてから術後照射を行なったもの $43 \%(3 / 7)$

D 外部照射のみのもの $0 \%(0 / 4)$

となり放射線照射のみしか行なえなかったものには 3 年生存者はいない。三者併用療法を行なったものでは,

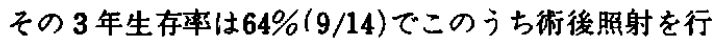
なわないですんだものは $80 \%$ の 3 年生存率を得ること ができた。

一方，一次治療後，術後照射を行なった症例の 3 年 生存率は $50 \%$ (11/22) であった。動注を行なわず手術

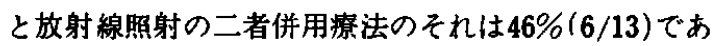
つた。

最近における抗癌郕の開発，放射線照射療法の進步 に伴ない，上䫓癌の治療成樍は年々向上している。わ れわれの場合も三者併用療法が円渭に行なわれた $\mathrm{A}(\mathrm{a})$ 群では $80 \% 3$ 年生存率を得ているが、三者併用療法が 遂行出来ず，二者併用療法であったり，または三者併 用療法で根治しえず照射を追加したような症例 $\mathrm{A}(\mathrm{b}$ h B， C，D群においてはA(a)群に比べてその生存率低 下が著しい。

すなわち，抗癌凨および放射線增感削の動注が副作 用その他のために完遂出来なかったり，癌の進行が著 しいために三者併用療法完了後, またはtumor dosis の遠隔照射後になお線維化された組樴に被覆されたま ま残された癌病巣が再僣した場合などが生存率低下の 大きな要因になっているといえよう。したがって上額 癌患者に对して三者併用撩法が円渭に行なえない場合
や，三者併用療法後に再燃する癌病巣に対する治䊗法 の進歩が今後の課題といえるのではないだろうか。

そこで動注，手術，照射などの治療後に杂洞化した 局所に，われわれは低線量率㓐内照射を行なっている。 一般に䶼内照射は $100 \mathrm{rad} / \mathrm{hr}$ 以上の線量率で治療され れているが、この場合正常組織の後障害, 癌細胞への 酸素供給の点で問題があるが，二の低線量率胫内照射

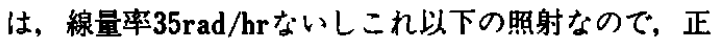
常組織に对して障害が少く, 低酸素圧癌細胞に効果的 に働くという実験的裹づけがある。

低線量率㓐内照射をはじめてまだ 2 年余りなので症 例は少く, 三者併用療法または二者併用療法後に行な

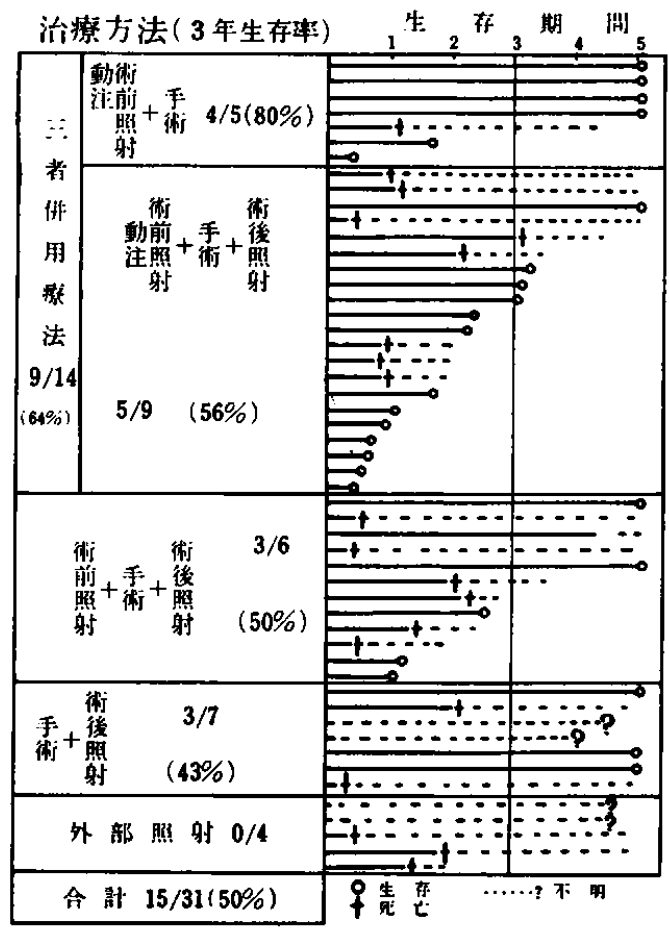




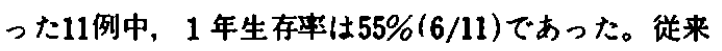
の術後外部照射や高線量本啌内照射を行なった22例の

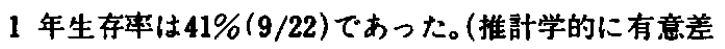

はない)またこの方法によって治療した症例について はいまだ再発、転移をみていない。 